DOI https://doi.org/10.18551/rjoas.2018-04.36

\title{
THE ANALYSIS OF AGRICULTURAL SECTOR'S GROWTH IN LHOKSEUMAWE OF INDONESIA
}

\author{
Angreani Putri \\ Post Graduate Program, Syiah Kuala University Banda Aceh Indonesia \\ Azhar, Mustafa \\ Faculty of Agriculture, Syiah Kuala University Banda Aceh Indonesia \\ Email: rani.farshi@gmail.com
}

\begin{abstract}
The purpose of this study was to determine and classify the growth of the agricultural sector in Lhokseumawe, and to identify the base and non-base sectors in each agricultural subsector. This research used Time Series GRDP data for 15 years of 2002-2016, Shift Share method, Klassen's Typology and Location Quotient analysis. The results of this study indicate that during study period the value of GRDP of Lhokseumawe city has been progressing, it is characterized by the influence of total growth value which indicates a positive value, and subsector that contributes the most is fishery sub-sector.
\end{abstract}

\section{KEY WORDS}

Shift Share, Klassen typology, location quotient, agricultural sector, growth.

Indonesia is one of the agrarian countries where most of its people live in rural areas and rely on agriculture. As Mubyarto (1995) points out, Indonesia is an agricultural country where agriculture plays an important role in the overall national economic conditions. The actual term of agriculture is the agriculture in a broader term, covering several fields: food crops sub-sector, horticulture crops, agricultural and hunting services, plantation crops subsector, farming sub-sector, logging and forestry sub-sector and fishery sub-sector. The agricultural sector is the primary sector where the output from agricultural sector will become an input by other sectors. Moreover, the natural resources of the agricultural sector is renewable, recyclable, growing or restock-able natural resources, in other words, natural resources that can continue to exist as long as not in over-exploited usage. With the diversity of commodities from various subsectors it is expected that the agricultural sector be able to give significant contribution to the region in Indonesia.

Regional economic development is often confronted with government policies that do not support the utilization and development of local potentials. Oktarina (2014) states that the growth of a region's agricultural sector is basically influenced by the region's competitive advantage, regional specialization and agricultural potential. The existence of agricultural potential in a region will remain useless for the growth of the region if there is no effort to utilize and develop agricultural potential optimally. Therefore, the utilization and development of all potential agricultural potentials should be a top priority to be explored and developed in implementing the intact development of agricultural areas. According to Arsyad (2010), the regional economic framework establishes a partnership pattern between the government and the private sector to create an employment and the development of regional economic activity. For the sake of the achievement of regional economic development goals, it require development policies which are based on local specificity (endogenous development), using local resource potentials.

The performance of a regional economy can be seen from the value of Gross Regional Domestic Product (GRDP) and its growth. GRDP serves as one of the indispensable economic indicators to measure the performance of a region's economic growth, either at current prices or at constant prices. Lhokseumawe has a 18,106 hectares land area, consist of 4 districts with agricultural potential spread almost evenly in each region. Based on GRDP 
data from 2007 to 2011 (Lhokseumawe dalam Angka 2013, 2014) there are 3 main sectors contributing to the regional economy: manufacturing, trade, hotel and restaurant sector and agriculture sector. The data shows that from the whole economic sector, the manufacturing sector contributes $54.12 \%$, the trade, hotel and restaurant sector is $24.63 \%$ and the agricultural sector $6.24 \%$. Subsectors that play an important role in the contribution of agriculture sector are fishery sub-sector, in 2007 until 2011 fishery sub-sector contributed $62,47 \%$ in development of Lhokseumawe's GRDP. This is strongly supported by the location of Lhokseumawe city, where geographically most of Lhokseumawe city is directly adjacent to the waters, and supported by natural resources consist of capture fishery and aquaculture fishery.

The revitalization of the agricultural sector needs to be done in an effort to support the economic development of Lhokseumawe. Revitalization of the agricultural sector is closely related to the existence of potential subsectors. According to Sudaryanto (2005), agricultural revitalization can be interpreted as an awareness to put back the importance of agriculture sector proportionally and contextually, through improving the performance of agricultural sector in national development with no disregard to other sectors. Agricultural revitalization is intended to raise the commitment and cooperation of all stakeholders and change the paradigm of the mindset of the community in viewing agriculture that is not just a consumption commodity producer, but must be able to see agriculture as a multi-functional sector and the source of life for most people.

The determination of potential subsectors is very important in agricultural development with the concept of efficiency to achieve comparative and competitive advantage in facing global trade. Identification and classification of agriculture sub-sector is needed to give the description of which sub-subsector whose activity become economic base or superior, potential, developing and also what is left behind, so that the priority sub-sector can be determined. Local governments need to make development strategies based on this priority so that agricultural development policy in the region can run optimally. Based on the classification, the government can also develop short-term, medium-term and long-term development programs which are also adapted to the development budget policy, especially agricultural development.

The scope of the study is limited to the GDRP of Lhokseumawe at 2000 constant prices from each subsector in agriculture sector for 15 years (2002-2016), including; a) Subsectors of Food Crops, Horticultural Plants, Agricultural Services and Hunting, b) Plantation Subsector, c) Livestock Subsector, d) Forestry and Logging Subsectors, and e) Fisheries Sub-sector. In addition, to complete this research data, it is required a comparison of variables (GRDP data) at the Aceh Province from 2002-2016.

\section{METHODS OF RESEARCH}

This research is done by using the library research approach, to strengthen the theoretical base that can support the research summarized from literature or scientific articles, and so forth. The type of data used in this study is secondary data, i.e. data obtained in 15 years' time series from 2002 to 2016, i.e. data collected from certain time series to provide an overview of the development of an activity during the period which specifically observed, this data is often also referred as historical data (Mudrajat, 2003), obtained from the agencies concerned with the research material. The methods used in analyzing data in this research are:

The concept of Shift Share Analysis (SS)ю Shift share analysis is used to determine changes and sector shifts in economy within a region. The result of shift share analysis will describe the performance of sectors in GRDP in the region compared to higher area (reference area), then analyzed the change of economic structure of a region by explaining the growth of the sector. So it can be known whether the growth of the area per sector is lower or higher than the reference area.

This analysis plays a role in providing data of the economic performance in three interrelated fields of each other, (Tarigan, 2005): 


$$
D_{i j}=N_{i j}+M_{i j}+C_{i j}
$$

Where:

1. Growth Impact (Nij) with (+) mark, implies a surplus, which means that subsectors in the study area grow higher than the average national growth, so be able to supply the needs of the reference region. While (-) mark implies a deficit, which means that subsector in study area growth slower than average national growth, so unable to supply requirement of reference area.

2. The industry mix (Mij) with (+) mark implies that the subsector (regional) is an advanced sub-sector, the subsector grows faster than the overall economic growth, otherwise (-) implies vice versa.

3. Competitive Advantage (Cij) shows the competitiveness of the subsector in the study area compared with the same subsector in the reference region.

The Concept of Klassen's Typology Analysis. Klassen's typology analysis is used to see the description of the pattern and growth structure of each economic sector. An overview of the pattern and structure of this region's growth can be used to predict future economic growth prospects for the region. In addition, it can also be used as a consideration in determining the policy of regional development. Klassen's Typology basically divides the region based on two main indicators: regional economic growth and per capita income area. The criteria used to divide the area of Lhokseumawe based on Klassen's Typology in this research are as follows:

4. Sub-sectors type I: fast-forward and fast-growing, areas which have higher economic growth and per capita income than the average of Aceh province.

5. Sub-sectors type II: advanced but under pressure, areas with higher per capita income, but economic growth rate are lower than the average of Aceh Province.

6. Sub-sectors type III: fast growing, areas with high growth rates, but per capita income level is lower than the average of Aceh Province.

7. Sub-sectors type IV: relatively underdeveloped, areas with lower economic growth and per capita income than the average of Aceh Province.

Table 1 - Classification of GRDP Sector according to Klassen's Typology

\begin{tabular}{|c|c|c|}
\hline growth rate $(r)$ & $y \mathrm{i}<\mathrm{y}$ & $y i>y$ \\
\hline Y & $\begin{array}{c}\text { Tipe III } \\
\text { Fast Growing }\end{array}$ & $\begin{array}{c}\text { Tipe I } \\
\text { Fast-Forward and Fast-Growing }\end{array}$ \\
\hline$r i<r$ & $\begin{array}{c}\text { Tipe IV } \\
\text { Relatively Underdeveloped }\end{array}$ & $\begin{array}{c}\text { Tipe II } \\
\text { Advanced but Under Pressure }\end{array}$ \\
\hline
\end{tabular}

Source: Sjafrizal, 1997.

Where:

- $\mathrm{Ri}=$ Economic growth rate of the study area;

- $r=$ Economic growth rate of the reference area;

- $y i=$ Revenue per capita of study area;

- $y=$ Revenue per capita of reference area.

Location Quotient Analysis Concept (LQ). According to Emilia (2006), LQ analysis is used to identify the economic base (base sector) of a region. With this analysis it can be known whether a region have base sector or superior (leading sector) level of specialization. The basic economic theory classifies all economic activities into two sectors i.e. the base sector and non-base sector. Base activities are activities of a society whose outcomes are either goods or services intended for export out of a community environment or outward, regional, national and international oriented (Rusastra et al 2002). While non-base activity is a community activity that results either in the form of goods or services destined for the community itself in the area of economic life of the community. The equations used are as follows: 


$$
L Q=\frac{E i j / E j}{E i n / E n}
$$

Where:

- $\quad \mathrm{LQ}=$ Location Quotient Coefficient;

- $\mathrm{Eij}=$ GRDP Sub-sector $\mathrm{i}$ in study area;

- $\mathrm{Ej}=$ Total GRDP in study area;

- Ein = GRDP Sub-sector $\mathrm{i}$ in reference area;

- $\mathrm{En}=$ Total GRDP in reference area.

From the results of this $L Q$ calculation can be seen that if:

1. LQ of a sub-sector $>1$ shows the corresponding sub-sectors including the base subsectors, which are prospectively to be further developed in an effort to improve the regional economy and meet the demand of either local, regional or national markets.

2. LQ of a sub-sector $<1$ indicates that the corresponding sub-sector does not include the leading sub-sector, which means that the subsector is less prospective to develop and there is a tendency to require demand from other regions.

3. $L Q$ a sub-sector $=1$ indicates that it has the same level of specialization with the same sub-subdivision in a larger area.

\section{RESULTS AND DISCUSSION}

Lhokseumawe is lowland with an average height of \pm 24 meters above sea level, and is located on the east coast of Sumatra Island. Geographically Lhokseumawe is positioned at $04^{\circ} 54^{\prime}-05^{\circ} 18^{\prime}$ North Latitude and $96^{\circ} 20^{\prime}-97^{\circ} 21^{\prime}$ East Longitude, flanked by the Malacca Strait, with the following territorial boundaries; Malaka Strait in the north, Regency of Kuta Makmur (North Aceh) in the south, Dewantara subdistrict (North Aceh) in the west and Syamtalira Bayu subdistrict (North Aceh).

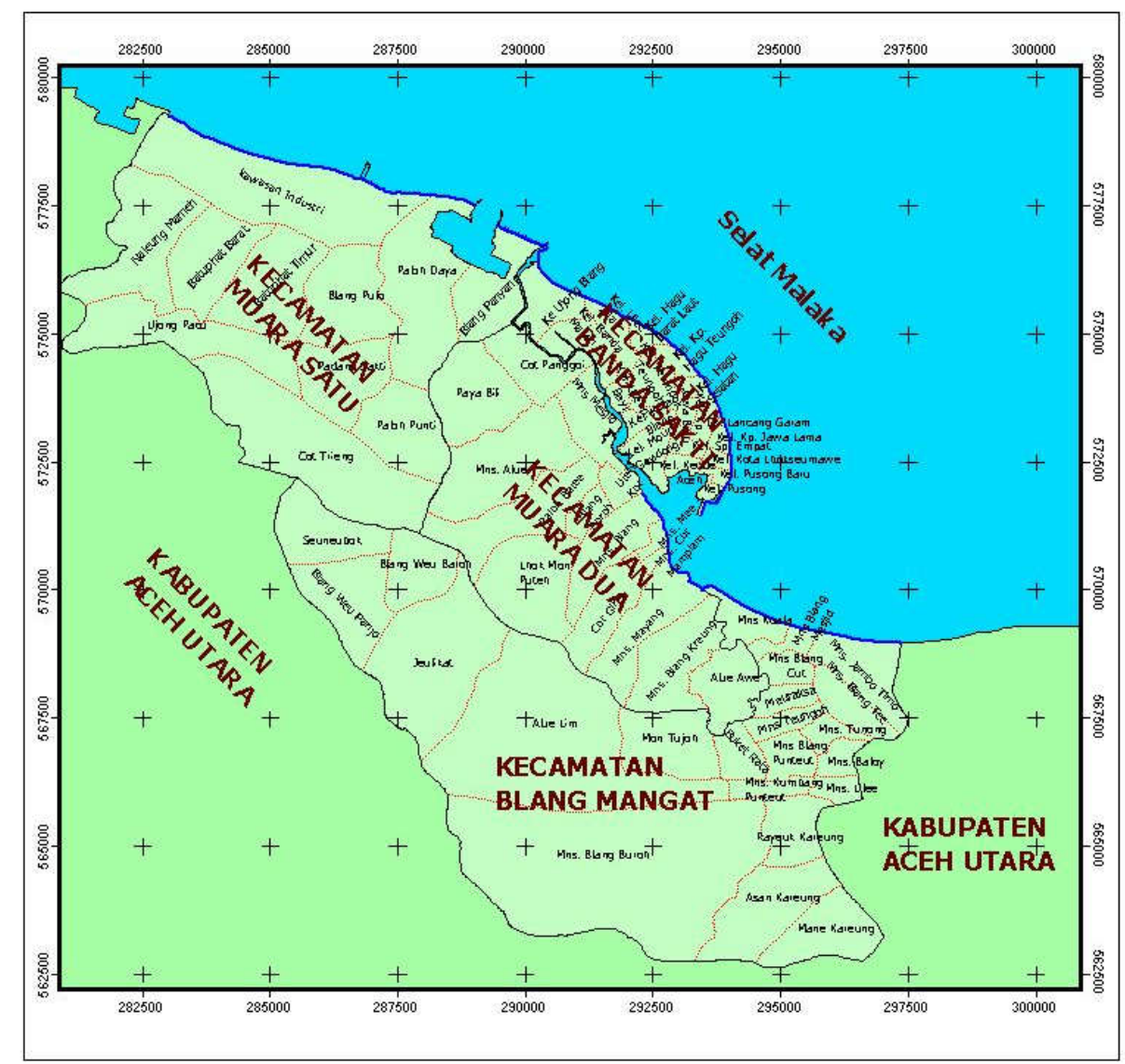

Figure 1 - The City of Lhokseumawe 
The agricultural sector has a stable role in the economy of Lhokseumawe. GRDP according to the Field of Business for Agriculture sector in Lhokseumawe, in 2002-2016 at constant price 2000 continued to increase, from 2002 Rp. 246,754.7 million up to 2006 up to Rp. 270,964.4 million, but decreased in 2007 up to Rp. 264,487.5 million and increased again in 2008 up to Rp. 267,243.3 million. In 2010 to 2016, the GRDP of Lhokseumawe has increased significantly. This is shown in Table 2 below.

Table 2 - The Development of GRDP at constant price 2000 Lhokseumawe Agricultural Sector during 2002-2016 (in million Rupiah)

\begin{tabular}{ccc}
\hline No & Year & GRDP \\
\hline 1 & 2002 & $246.754,7$ \\
2 & 2003 & $253.268,8$ \\
3 & 2004 & $261.244,2$ \\
4 & 2005 & $266.029,5$ \\
5 & 2006 & $270.964,4$ \\
6 & 2007 & $264.487,5$ \\
7 & 2008 & $267.243,3$ \\
8 & 2009 & $269.064,6$ \\
9 & 2010 & $452.117,2$ \\
10 & 2011 & $469.141,3$ \\
11 & 2012 & $487.026,7$ \\
12 & 2013 & $502.309,1$ \\
13 & 2014 & $506.319,0$ \\
15 & 2015 & $516.413,7$ \\
\hline
\end{tabular}

Source: BPS Lhokseumawe, 2017.

Shift Share analysis is used to see the economic growth process of Lhokseumawe which is associated with Aceh Province as the regional economy that become reference. Shift Share analysis in this study is using income variable, PDRB ADHK 2000 to describe economic growth in the city of Lhokseumawe. From this analysis it can also be known the development of a sector or sub-sector in a region when relatively compared to other sectors or subsectors, whether the growth is fast or slow. In this analysis the components of economic growth are divided into three, i.e. the national growth component (Nij), the industry mix component (Mij) and the competitive advantage component (Cij). The result of calculation of Shift Share analysis of GRDP of Lhokseumawe in 2002-2016 is shown in table 3. Based on the result of Shift Share analysis shows that during the period of 15 years from 2002-2016, the value of GRDP of agriculture sub-sector of Lhokseumawe has developed.

Table 3 - The Calculation Results of Shift Share Analysis of Agricultural Sector of Lhokseumawe at constant price 2000, During 2002-2016 (in million rupiah)

\begin{tabular}{|c|c|c|c|c|c|}
\hline \multirow[b]{2}{*}{ No } & \multirow[b]{2}{*}{ Agricultural Sector } & \multicolumn{3}{|l|}{ Components } & \multirow{2}{*}{$\begin{array}{l}\text { Economic Structure } \\
\text { Shift } \\
\text { Total } \\
\text { Growth } \\
\text { (Dij) }\end{array}$} \\
\hline & & $\begin{array}{l}\text { National Growth } \\
\text { (Nij) }\end{array}$ & $\begin{array}{l}\text { Industry Mix } \\
\text { (Mij) }\end{array}$ & $\begin{array}{l}\text { Competitive } \\
\text { Advantage } \\
\text { (Cij) }\end{array}$ & \\
\hline 1. & $\begin{array}{l}\text { Food Crop, Horticultural } \\
\text { Crop, Agricultural } \\
\text { Services and Hunting }\end{array}$ & $576.641,54$ & $109.084,09$ & $(697.276,75)$ & $(11.551,12)$ \\
\hline 2. & Plantation & $65.667,13$ & $50.019,54$ & $(92.819,45)$ & $22.867,22$ \\
\hline 3. & Livestock & $850.150,90$ & $(256.691,16)$ & $(629.029,54)$ & $(35.569,80)$ \\
\hline 4. & Forestry and Logging & $2.507,61$ & $(1.612,60)$ & $2.648,73$ & $3.543,74$ \\
\hline 5. & Fishery & $1.320 .672,94$ & $(255.844,33)$ & $(761.027,42)$ & $303.801,19$ \\
\hline Total & & $2.815 .640,13$ & $(355.044,47)$ & $(2.177 .504,42)$ & $283.091,23$ \\
\hline
\end{tabular}

Source: Results of Processed Data, 2018.

According to the calculation of the National Growth component $\left(\mathrm{N}_{\mathrm{ij}}\right)$ all subsectors are positive, means that growth in Lhokseumawe is faster than the Aceh Province. The highest 
positive sub-sector is the fishery sub-sector of Rp. 1,320,672.94 million, and the sub-sector with the lowest positive value is the forestry and logging sub-sector of Rp. 2,507.61 million. The Industrial Mix component $\left(\mathrm{M}_{\mathrm{ij}}\right)$ represents a major change in the region's economy due to the industry mix. The growth of Industrial Mix components $\left(\mathrm{M}_{\mathrm{ij}}\right)$ is positive and negative. The positive $M_{i j}$ value signifies the economy of Lhokseumawe specializing in the same sub-sector at Aceh Province growing fast. Conversely, if $\mathrm{M}_{\mathrm{ij}}$ is negative), it means that the economy of Lhokseumawe city specializes in the slow-growing subsector of the economy of Aceh Province. Subsectors with positive industry mix values are food crops, horticultural crops, agricultural and hunting services and plantation sub-sectors. The largest sub-sectors in supporting the industry mix component are food crops, horticulture, agriculture and hunting, which are Rp. 109,084.09 million.

Competitive Advantage components $\left(C_{i j}\right)$ Lhokseumawe economy during 2002-2016 there is a positive and negative value. A positive $C_{i j}$ score means that there is a sub-sector that grows faster than the level of Aceh Province. While the negative $C_{i j}$ value indicates the subsector is growing slower than Aceh Province. There is one sub-sector with positive $\mathrm{C}_{\mathrm{ij}}$ value, that is Forestry sub-sector and logging is Rp. 2,648.73 million. While the other four sub-sectors have negative $C_{i j}$ values, i.e food crops sub-sector, horticultural crops, agricultural and hunting services, plantation sub-sector; livestock sub-sector; and fishery subsector. The influence of total growth value of GRDP $\left(D_{i j}\right)$ in Lhokseumawe shows positive value that is growing by $\mathrm{Rp}$. 283,091.23 million. The biggest contribution contributed by the fishery sub-sector is Rp. 303,801.19 million.

Klassen's Typology analysis is used to find out the description of regional economic status. This analysis basically divides the region based on two indicators: regional economic growth and regional per capita income by determining the average of economic growth as the vertical axis and average per capita income as the horizontal axis. The subsectors observed were divided into four quadrants as follows:

1. The high growth and high income sub-sector is where the growth rate of GRDP and per capita income in regions is higher than the average growth and income per capita of the province average.

2. The high income but low growth sub-sector is a relatively advanced sub-sector, but in recent years the rate of growth has declined. Regional per capita revenues are higher than the provincial average per capita income, but the economic growth rate is lower than the provincial average.

3. The high growth but low income sub-sector is a fast-growing sub-sector with very large development potential but not fully processed properly. The growth rate of the regions is high but the per capita income level is lower than the provincial average.

4. The low growth and low income sub-sectors are subsectors that still have growth rates and per capita income lower than the provincial average.

The results of the calculation of Klassen's Tipology analysis for the agricultural sector of Lhokseumawe during 2002 - 2016 are shown in Table 4 below:

Table 4 - The results of the calculation of Klassen's Tipology analysis for the Agricultural Sector of Lhokseumawe at constant price 2000 during 2002 - 2016 (percentage)

\begin{tabular}{|c|c|c|c|c|c|c|}
\hline \multirow[b]{2}{*}{ No } & \multirow[b]{2}{*}{ Agricultural Sector } & \multicolumn{2}{|c|}{ Lhokseumawe } & \multicolumn{2}{|l|}{ Aceh } & \multirow[b]{2}{*}{ Quadrant } \\
\hline & & $\begin{array}{l}\text { Growth } \\
\text { Rate } \\
(\%)\end{array}$ & $\begin{array}{l}\text { Per Capita } \\
\text { Income } \\
\text { Rate } \\
(\%)\end{array}$ & $\begin{array}{l}\text { Growth } \\
\text { Rate } \\
(\%)\end{array}$ & $\begin{array}{l}\text { Per Capita } \\
\text { Income } \\
\text { RAte } \\
(\%)\end{array}$ & \\
\hline 1. & $\begin{array}{l}\text { Food Crop, Horticultural Crop, } \\
\text { Agricultural Services and Hunting }\end{array}$ & $-5,71$ & 11,53 & 339,23 & 36,11 & 4 \\
\hline 2. & Plantation & 99,34 & 4,43 & 502,56 & 26,78 & 4 \\
\hline 3. & Livestock & $-11,94$ & 14,61 & 199,13 & 14,54 & 2 \\
\hline 4. & Forestry and Logging & 403,14 & 0,51 & 101,82 & 5,99 & 3 \\
\hline 5. & Fishery & 65,62 & 68,93 & 230,00 & 16,58 & 2 \\
\hline \multicolumn{2}{|c|}{ Total } & 550,45 & 100 & $1.372,00$ & 100 & \\
\hline
\end{tabular}

Source: Results of Processed Data, 2018. 
Based on Table 4 above, it shows that the sub-sector classified to the high income but low growth quadrant is livestock sub-sectors where the average value of growth is lower than that of Aceh province by $-11.94 \%$, but the average value of per capita income is higher than Province Aceh is $14.61 \%$ and fisheries sub-sector where the average value of growth is lower than the province of Aceh that is equal to $65.62 \%$, but the average value of per capita income is higher than the province of Aceh that is equal to $68.93 \%$. Subsectors included in the high growth but low income quadrants are the forestry and logging sub-sectors where the average value of growth is higher than that of Aceh province at $403.14 \%$, but the average per capita income is lower than that of Aceh at $0.51 \%$, while the sub-sectors which falling into low growth and low income quadrants are food crops, horticultural crops, agricultural and hunting services, where the average value of growth and income per capita is lower than that of Aceh Province of $-5.71 \%$ and $11.53 \%$, and the plantation sub-sector where the average value of growth and income per capita is lower than that of Aceh Province of $99.34 \%$ and $4.43 \%$ each, For more details, the division of quadrants in the agricultural subsector in Lhokseumawe can be seen in table 5 below:

Table 5 - Klassen's Typology Quadrant of Agricultural Sector

\begin{tabular}{|c|c|c|}
\hline Criteria & yi $<y$ & $y i>y$ \\
\hline$r i>r$ & $\begin{array}{l}\text { Quadrant III } \\
\text { (Fast Growing) } \\
\text { Forest yang Logging Sub-Sector }\end{array}$ & $\begin{array}{l}\text { Quadrant I } \\
\text { (Fast-Forward and Fast-Growing) } \\
\text { None }\end{array}$ \\
\hline$r i<r$ & $\begin{array}{l}\text { Quadrant IV } \\
\text { (Relatively Underdeveloped) } \\
\text { Food Crop, Horticultural Crop, Agricultural and } \\
\text { Hunting Services Sub-Sector } \\
\text { Plantation Sub-Sector }\end{array}$ & $\begin{array}{l}\text { Quadrant II } \\
\text { (Advanced but Under Pressure) } \\
\text { Livestock Sub-Sector } \\
\text { Fishery Sub-Sector }\end{array}$ \\
\hline
\end{tabular}

Source: Results of Processed Data, 2018.

Location Quotient analysis is used to determine which sectors or subsectors of the economy in GRDP can be classified into base sectors or subsectors and non-base sectors or sub-sectors. Location Quotient is a comparison of the magnitude of the role of a sector or subsector in Lhokseumawe to the magnitude of the role of the sector or subsector at Aceh Province. If the calculation results show more than $1(L Q>1)$, it means that the sub-sector is the base subsector and the role of sub-sector in Lhokseumawe is more prominent than the role of sub-sector in Aceh Province, in other words, the subsector is superior and potential subsector developed as a driving force for the region's economy. Otherwise, if the calculation results show less than $1(L Q<1)$, it means that the sub-sector is non-base sub-sector and the role of sub-sector in Lhokseumawe is smaller than the sub-sector in Aceh Province, in other words, the sector is not a leading sector and less potential to be developed as a driver of the region's economy. The result of the calculation of Location Quotient of Lhokseumawe for the last 15 years (2002-2016) is shown in table 6 below:

Table 6 - Average LQ Calculation Index of Agriculture Sector Analysis

\begin{tabular}{clcc}
\hline \multirow{2}{*}{ No } & \multirow{2}{*}{ Sub-Sector } & \multicolumn{2}{c}{ Average LQ Value (2002 - 2016) } \\
\cline { 3 - 4 } & & Value & Description \\
\hline 1. & Food Crop, Horticultural Crop, Agricultural and Hunting Services & 0,38 & Non Base \\
2. & Plantation & 0,17 & Non Base \\
3. & Livestock & 1,18 & Base \\
4. & Forestry and Logging & 0,07 & Non Base \\
5. & Fishery & 3,59 & Base \\
\hline
\end{tabular}

Source: Results of Processed Data, 2018.

Based on the calculation of Location Quetiont in the table above, Lhokseumawe for the last 15 years has on average two base sub-sectors when viewed from the average index of Location Quotient greater than 1 (LQ> 1), which is fishery sub-sector with $L Q$ index an average of 3.59 where this subsector is the base subsector with the largest average index. 
And the livestock sub-sector is the second largest sub-sector with an average LQ index of 1.18. This indicates that both sub-sectors have good economic strength and have an influence on increasing economic growth of Lhokseumawe, and both sub-sectors have been able to fulfill consumption needs in the area. Arsyad (2010) states that the base sector needs to be prioritized to be developed in order to refer to regional economic growth.

Meanwhile, there were 3 sub-sectors included in the non-base subsector during the period 2002-2016 where the average index of Location Quotient showed less than 1 (LQ <1), i.e. food crops, horticultural crops, agricultural and hunting services with LQ index average of 0.38 , plantation subsector with an average $L Q$ index of 0.17 and forestry and logging subsectors with an average LQ index of 0.07 . The production of these three sub-sectors still have not been able to meet the consumption needs in Lhokseumawe so that it must import from outside the region.

\section{CONCLUSION}

The result of Shift Share analysis, on the national growth of all agricultural sub-sectors in Lhokseumawe is positive and influenced by agricultural economy in Aceh. In the industry mix, the result of agricultural sub-sector development is still slower than other economic sectors in Lhokseumawe. On competitive advantage is dominated by negative values where the agricultural sub-sector is not sufficiently competitive with other districts / cities in Aceh province. The sub-sectors that contribute substantially to Lhokseumawe's economy in the agricultural sector is the fisheries sub-sector.

The result of Klassen's Typology analysis, the agricultural sub-sector in Lhokseumawe city is classified into three quadrant of Klassen's Typology, as follows:

(1) The subsector in quadrant 2 (advanced but under pressure sub-sector) including livestock sub-sector with average value of growth equal to $-11,94 \%$ and average value of income per capita equal to $14,61 \%$, and fishery sub-sector with value of growth average equal to $65,62 \%$ and average per capita income of $68.93 \%$.

(2) The subsector in quadrant 3 (fast growing sub-sector) including forestry and logging subsector with average growth value $403,14 \%$ and average value of income per capita equal to $0,51 \%$.

(3) The subsector in quadrant 4 (relatively underdeveloped sub-sector) including food crops, horticulture, agriculture and hunting with average growth rate of $-5,71 \%$ and average value of income per capita is $11,53 \%$ and plantation sub-sector with an average growth rate of $99.34 \%$ and an average per capita income of $4.43 \%$.

The result of Location Quotient analysis, the base sub-sector (LQ>1) in Lhokseumawe city is livestock sub-sector with average of 1.18 and fishery sub-sector with an average of 3.59. While the sub-sectors classified to the non-base sub-sector $(L Q<1)$ are the food crops, horticultural crops, agricultural and hunting services with an average of 0.38 , the plantation sub-sector with an average of 0.17 and the forestry and logging sub-sectors with average of 0.07 .

\section{REFERENCES}

1. Arsyad, L. (2010). Ekonomi Pembangunan, Edisi 4. Yogyakarta: STIE YKPN.

2. Astuti, H dan Sumarlin. (2013). Analisis Komoditas Unggulan Tanaman Pangan dan Kinerja terhadap Pembangunan Pertanian di Kabupaten Lampung Barat. Kelitbangan (Inovasi dan Pembangunan).

3. Azhar, S. L. Fuaidah dan M. N. Abdussamad. (2005). Analisis Sektor Basis dan Non Basis Di Propinsi Nanggroe Aceh Darussalam. SOCA (Socio-Economic of Agriculture and Agribusiness, 5:1-9.

4. Bannock, G. (2004). A dictionary of economics. Retrieved April 22, 2013, from Wikipedia: http://id.wikipedia.org/wiki/Pembangunan_ekonomi

5. Bappeda. (2012). Rencana Program Investasi Jangka Menengah (RPIJM) Kota Lhokseumawe 2013-2017. Lhokseumawe: Bappeda. 
6. Cahyono, S. A. (2015). Pertumbuhan dan Ketimpangan Ekonomi Di Daerah Aliran Sungai Begawan Solo. Jurnal Penelitian Hutan dan Konservasi Alam, Vol. 12 No. 1.

7. Emilia. (2006). Menggagas Standar Audit Program CSR: Initiating Audit Standard of CSR Program. Bandung: Sekolah Tinggi Kesejahteraan Sosial.

8. Ermalina., Efriadi., Masduki. (Vol. 5 No. 2 Agustus 2017). Tingkat Ketimpangan dan Desentralisasi Fiskal Provinsi Banten. Jurnal IImiah Gema Ekonomi, 717-736.

9. Glasson, J. (1990). Pengantar Perencanaan Regional (terjemahan Paul Sitohang). Jakarta: FE UI.

10. Hadi, Sutrisno. (2004). Penelitian Research. Yogyakarta: BPFE.

11. Hendayana, R. (2003). Aplikasi Metode Location Quotient (LQ) dalam Penentuan Komoditas Unggulan Nasional. Majalah Informatika Pertanian.

12. Hermanto dan G. S. Hardono. (2017). Dinamika PDB Sektor Pertanian dan Pendapatan Petani. Retrieved April 26, 2017, from Litbang Pertanian: http://pse.litbang.pertanian.go.id/ind/pdffiles/patanas/2_1_buku_1.pdf

13. Hood, R. (1998). Economic Analysis: A location Quotient. Primer Principal. Sun Region Associates, Inc .

14. Irawan. (2014). Ekonomi Pembangunan. Yogjakarta: BPFE.

15. Irmansyah. (2016). Pabrik Es. Retrieved March 20, 2018, from http://portalsatu.com/read/ekbis/pabrik-es-pusong-mati-di-lumbung-ikan-20084.

16. Kuncoro, M. (2003). Metode Riset untuk Bisnis dan Ekonomi. Jakarta: Erlangga.

17. Kurniati, S. A. (Vol. XXIX). Analisis Pertumbuhan Ekonomi dan Pengembangan Sektor Potensial di Kabupaten Siak. Jurnal Dinamika Pertanian, 263-270.

18. Lestari, P. i. (2017). Hubungan Antara Pebiayaan Dengan Pengembangan Sektor Ekonomi Unggulan Pada Industri Perbankan Syariah Di Sumatera. Jurnal Ecoment Global: Kajian Bisnis dan Manajemen, Vol. 2 No. 1.

19. Lindert, P. H dan C. P. Kindleberger. (1995). Ekonomi Internasional. Jakarta: Erlangga.

20. Mubyarto. (1995). Pengantar Ekonomi Pertanian. Jakarta: PT. Pusaka LP3ES Indonesia, anggota IKAPI.

21. Munir, Sirajul. (2017). Kembangkan Sektor Perikanan. Retrieved March 20, 2018, from http://portalsatu.com/read/news/irwandi-suaidi-yahya-harus-kembangkan-sektor perikanan-31686.

22. Oktarina, D. (2014). Analisis Komoditas Unggulan Tanaman Pangan di Kabupaten Ogan Komering Ulu Timur. BKS PTN Barat, (pp. 922-927). Bandar Lampung.

23. Porter, M. (1990). The Competitive Advantage of Nations. Macmillan: Free Press.

24. Prianto, F. W. (2011). Pola Pengembangan Agroindustri Yang Berdaya Saing (Studi Kasus Kabupaten Malang). Jeam Vol. X No. 1, 48-71.

25. Rahajeng, A. (2014). Modul Praktikum Perencanaan Pembangunan Daerah . Yogjakarta: Diploma Ekonomika dan Bisnis Universitas Gadjah Mada.

26. Richardson, H. W. (1969). Regional Economic. Location Theory, Urban Structure and Regional Change. Word University Weidenfeld and Nicholson.

27. Rusastra, I, W., P. Simatupang dan B. Rachman. (2002). Pembangunan Ekonomi Perdesaan Berbasis Agribisnis, Analisis Kebijakan: Pembangunan Pertanian Andalan Berwawasan Agribisnis. Bogor: Pusat Penelitian Sosial Ekonomi Pertanian.

28. Selvia Elysanti, Teguh Hadi P dan Herman Cahyo D. (2015). Analisis Tipologi dan Sektor Potensial dalam Pengembangan Ekonomi Wilayah Kecamatan di Kabupaten Jember. Artikel IImiah Mahasiswa.

29. Shields, M. (2003). Using Employment Data to Better Understand Your Local Economy, Agricultural Research and Cooperative Extension. Pennsylvania: The Pennsylvania State University.

30. Sjafrizal. (1997). Pertumbuhan Ekonomi dan Ketimpangan Regional Wilayah Indonesia Bagian Barat. Prisma Jakarta LP3ES, No. 3 Tahun XXVI.

31. Statistik, B. P. (2014). Lhokseumawe dalam Angka 2013. Lhokseumawe: Badan Pusat Statistik.

32. Statistik, B. P. (2016). Lhokseumawe dalam Angka 2015. Lhokseumawe: Badan Pusat Statistik. 
33. Sudaryanto, T. A. (Desember 2005). Pelaksanaan Revitalisasi Pertanian. Agrimedia, Volume 10, No.2.

34. Tarigan, R. (2005). Perencanaan Pembangunan Wilayah. Jakarta: Bumi Aksara.

35. Todaro, M. P. (2003). Pembangunan Ekonomi di Dunia Ketiga, Edisi 8. Jakarta: Erlangga.

36. Vikaliana, R. (Vol. 9 No. 2 September 2017). Analisis Identifikasi Sektor Perekonomian Sebagai Sektor Basis dan Sektor Potensial Di Kota Bogor. Transparansi Jurnal IImiah IImu Administrasi, 198-208.

37. Wicaksono, I. A. (2011). Analisis Location Quotient Sektor Dan Subsektor Pertanian Pada Kecamatan Di Kabupaten Purworejo. Mediagro Vol. 7 No. 2, 11-18.

38. Widiarsih, D. (2016). Analisa Potensi Ekonomi Daerah Di Provinsi Kepulauan Bangka Belitung. Jurnal Akuntansi dan Ekonomika, Vol. 6 No. 2.

39. Yas. (2012). Potensi Sektor Perikanan Lhokseumawe. Retrieved March 20, 2018, from http://sumaterapost.com/berita1/Jepang-Lirik-Potensi-Sektor-Perikanan Lhokseumawe21616

40. Yusuf, M. (1999). Model Rasio Pertumbuhan (MRP) sebagai Salah Satu Alat Analisis Alternatif dalam Perencanaan Wilayah dan Kota Aplikasi Model Wilayah BangkaBelitung. Ekonomi dan Keuangan Indonesia, 105-233. 